\title{
Detection Combustion Data Pattern on Gasoline Fuel Motorcycle with Carburetor System
}

\author{
Andrizal $^{\#}$, Budhi Bakhtiar ${ }^{\#}$ and Rivanol Chadry* \\ \# Electrical Department, Polytechnics State of Padang, Padang, West Sumatera, Indonesia \\ E-mail: andrizalpoli@gmail.com; budhi_5bach@yahoo.com \\ * Mechanical Department, Polytechnics State of Padang, Padang, West Sumatera, Indonesia \\ E-mail: rivanolchadry@yahoo.com
}

\begin{abstract}
Tune up combustion motorcycle engine made in order to obtain a perfect engine combustion category with maximum engine performance and fuel efficiency. Motorcycles with 4-stroke petrol injection system has facilities to process tune up in the form of engine control unit and engine scanner tool. While petrol 4 stroke motorcycle carburetor system is not equipped with facilities such as a motorcycle injection system, consequently, tune up the engine combustion process is done manually. Category of the combustion engine can be determined based on the levels of emissions of $\mathrm{HC}, \mathrm{CO}, \mathrm{CO} 2$ and $\mathrm{O} 2$ contained in the exhaust gases of vehicles. This study aims to create a system to detect and display patterns of data categories motorcycle combustion gasoline engine carburetor system through the detection of exhaust emissions. This system is made using four gas sensors are integrated with the system FPGA (Field Progrmable Gate Array) as the main system and a display system using a PC or Laptop. Tests performed on a number of motorcycles with the brand, manufacturer and year of manufacture are different. Detection results shown in graphical form a pattern data categories perfect combustion engine and the data pattern of incomplete combustion category with a response time to 10 seconds. This system is expected to be used as an alternative tool for mechanics in performing tune up combustion motorcycle engine.
\end{abstract}

Keywords - exhaust; combustion pattern data; gasoline; carburetor system

\section{INTRODUCTION}

One of the routine activities undertaken by motorcycle owners is to tuning the machine in the simplest way so that the bike is always on its maximum performance. One of the tune up on machine that is often done is tuning up the combustion engine. The purpose of this process is to enable the efficient use of fuel with a maximum power generated or also called a complete combustion. The complete combustion is characterized by the balance between fuel, air and ignition in the combustion chamber. While the incomplete combustion said if there is an imbalance between air, fuel and ignition in the combustion chamber. As a result of the incomplete combustion are the engine performance that is not not optimal, wasteful of fuel, high exhaust emissions and the exhaust emission standards that is not appropriate [1]

Tune up process in motorcycle with injection system, carried out by a mechanic with the assistance of detection devices which is often called a scanner engine. This system is capable of detecting and simultaneously petrified to tun up the engine combustion process which is set the fuel, air and ignition of the vehicle in order to obtain a complete engine combustion conditions. Engine scanner works based on the results of data detection sensors that is attached to vehicle exhaust emissions channel is integrated with the Engine Control Unit (ECU) [2]. ECU serves as an automatic control system of motorcycle engines, one of which is a control system of combustion engines [1]. As for motorcycle carburetor system is not equipped with a system of sensors and ECU that controls the combustion system is done mechanically.

In the motorcycle with carburettor system, tune up the engine combustion is done manually and based on the experience of a mechanic. There are several ways used to do, such as listening to the rhythm of machine, see the colour of the exhaust gases, looking at the combustion of the spark plugs. Or more extreme a mechanic will smell the exhaust emissions of the combustion on the spark plugs directly.

There are several elements and compounds in motorized vehicles exhaust emissions of gasoline. Levels of gas elements and compounds contained in exhaust emissions will determine the category of the motorcycle combustion engine [1][3][4]. On exhaust emissions, which are crucial in determining the category of the engine combustion is carbon 
monoxide gas $(\mathrm{CO})$, carbon dioxide $\left(\mathrm{CO}_{2}\right)$, hydrocarbons (HC) and oxygen $\left(\mathrm{O}_{2}\right)$, as shown in Table 1 [5].

TABLE I

THE CONDITION AND THE TYPE OF COMBUSTION ENGINE BASED ON THE LEVELS OF ELEMENTS AND COMPOUNDS EXHAUST GAS .

\begin{tabular}{|l|l|l|l|l|}
\hline \multicolumn{4}{|c|}{ Elements and compound Gas } & \multicolumn{1}{c|}{$\begin{array}{c}\text { Conditions Combustion } \\
\text { Engines }\end{array}$} \\
\hline CO & CO 2 & HC & O 2 & \\
\hline H & L & H & H & Not Perfect \\
\hline H & L & H & L & Not Perfect \\
\hline L & L & L & H & Not Perfect \\
\hline L & H & L & H & Not Perfect \\
\hline H & L & M & H & Not Perfect \\
\hline H & H & H & H & Not Perfect \\
\hline L & L & H & H & Not Perfect \\
\hline L & H & L & L & Perfect \\
\hline
\end{tabular}

$H=$ High, $L=$ Low, $M=$ Medium

To get the complete combustion on motorcycle required a balance quantity of fuel, ignition and air entering the combustion chamber through the carburetor settings on the system. The results of complete combustion can be detected through the levels of exhaust emissions based on reference standards. Table 1 and Table 2 displays the category of complete combustion with lower levels of $\mathrm{HC}, \mathrm{CO}$ low, high $\mathrm{CO}_{2}$ and low $\mathrm{O}_{2}$.

Table 2. The exhaust emission standards for motorcycle carburetor gasoline fuel system for complete combustion categories [5][6].

TABLE II

THE EXHAUST EMISSION STANDARDS FOR MOTORCYCLE CARBURETOR GASOLINE FUEL SYSTEM FOR COMPLETE COMBUSTION CATEGORY .

\begin{tabular}{|l|l|l|}
\hline $\begin{array}{l}\text { the type of } \\
\text { gas }\end{array}$ & gas levels & indicator \\
\hline $\mathrm{HC}$ & $\begin{array}{l}200 \mathrm{ppm}-400 \mathrm{ppm} \\
0,02 \%-0,04 \%\end{array}$ & atau \\
\hline $\mathrm{CO}$ & $1,5 \%-2 \%$ & Low \\
\hline $\mathrm{CO}_{2}$ & $12 \%-15 \%$ & Low \\
\hline $\mathrm{O}_{2}$ & $0,5 \%-2 \%$ & High \\
\hline
\end{tabular}

Perfect combustion engines will also produce exhaust emissions in accordance with the standard exhaust emissions limits are permissible. In Indonesia, based on the Ministry of the Environment No. 5 of 2005 for a motorcycle fuel tank is a maximum of $5.5 \% \mathrm{CO}$ and $\mathrm{HC}$ maximum of $2400 \mathrm{ppm}$ [6].

The levels of elements and compounds of the exhaust gases can be detected using gas sensors that are sensitive to gas elements and compounds $\mathrm{HC}, \mathrm{CO}, \mathrm{CO}_{2}$ and $\mathrm{O}_{2}$ [7];[8] [9];[10]. In order to process the sensor signal with the analog data and in the time domain is converted into a digital value and the frequency domain before being processed to make the data pattern engine combustion conditions.

Fast Fourier Transform (FFT) process is performed to change the signal detected in the span (time domain) into signals in the frequency domain are displayed in the form of the spectrum to the value of a certain magnitude. The results of spectrum frequency domain is processed and analysed to choose a particular frequency which represents the unique characteristics of the category of the combustion engine.

To ease understanding and reading the detection result of combustion, it is presented in the form of graphic data pattern that has a value of magnitude. Display data patterns will be defined as information or characteristics of the detected engine combustion category. Changes in the value of the magnitude of pattern data can be displayed in real time in accordance with changes in gas elements and compounds.

The final results that is expected from this research are: (1). Design and makes the system capable of detecting characteristic in the form of a data pattern category of motorcycle engine combustion using gasoline fuel in realtime through the detection of exhaust emissions based multi gas sensor. (2). The pattern of the data generated by the system can be used as a reference for a mechanic as an alternative data when performing a tune up the combustion engine in order to obtain perfect combustion category.

\section{METHODS}

The size of the gas that content elements and compounds $\mathrm{HC}, \mathrm{CO}$ and $\mathrm{CO} 2$ and $\mathrm{O} 2$ greatly affect the performance of the machine [1]. Excessive exhaust emissions indicates wasteful fuel, so that the combustion engine is not perfect [1]. Engine with fuel injection technology electronically (Electronic Fuel Injection) uses an electronic system to regulate air flow system, the fuel and ignition automatically causing complete combustion conditions. this is evidenced by the levels of exhaust emissions that is lower and environmentally friendly [1],[2]. Motorcycle with the manufacture before the year 2000 have the result of high emissions, it is strongly associated with the combustion control system on the engine fuel system [11],[12].

Based on the results of previous studies that the levels of elements and compounds exhaust emissions will determine the condition of the motorcycle combustion engine. Perfect combustion engine will produce levels of elements and compounds that is lower emissions while incomplete combustion engines produce high levels of elements and compounds such high emissions in Table 1. Thus, to obtain a perfect combustion process while tuning up the combustion of a motorcycle using gasoline fuel carburetor system needed a tool that can detect the combustion category is based on the levels of exhaust emissions.

According to data from the Central Statistics Agency (BPS), motorcycle users in Indonesia by 2013 was $84,732,652$. With growth of $12 \%$ per year, it is predicted that in 2015 there were \pm 100 million and an estimated $40 \%$ to $60 \%$ (40 million-60 million) is motorcycle carburetor system. Thus there is still a lot of motorcycle with carburetor system being used by the today's society.

\section{RESULTS AND DISCUSSIONS}

This system is a type of embedded systems consisting of modules FPGA (Field Programmable Gate Array) as the main system [13][14], and Laptop / Note book as a display system output. Components of the sensor used are KE 50 for $\mathrm{O}_{2}$, MQ 135 for the $\mathrm{CO}_{2}, \mathrm{CO}$ and MQ 7 for TGS 2201 for the HC [7][8]. Data transmission between system myRIO the display system is done with the wireless network communication. 


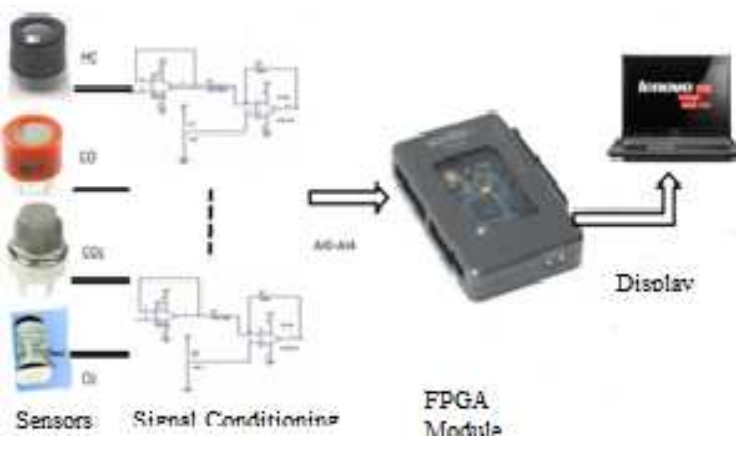

Fig.1. Diagram of the relations system.

Display intermediaries with the system shown in Figure 2.

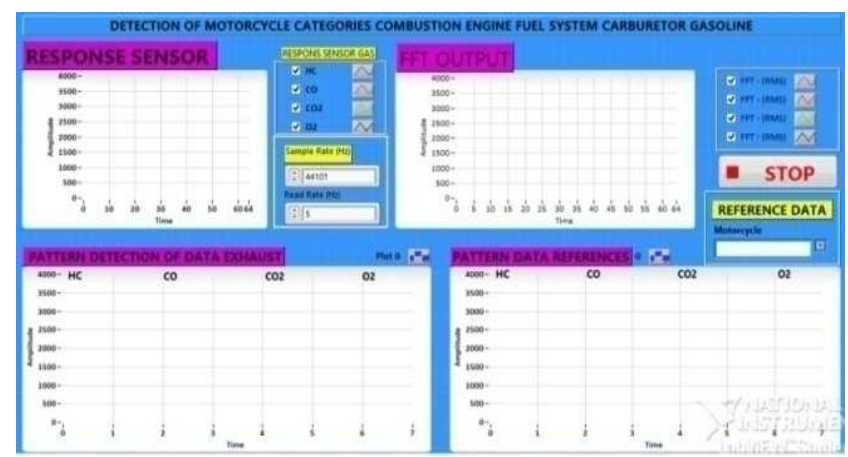

Fig.2. The front panel display

Block diagram or data flow program that created the system shown in Figure 2.

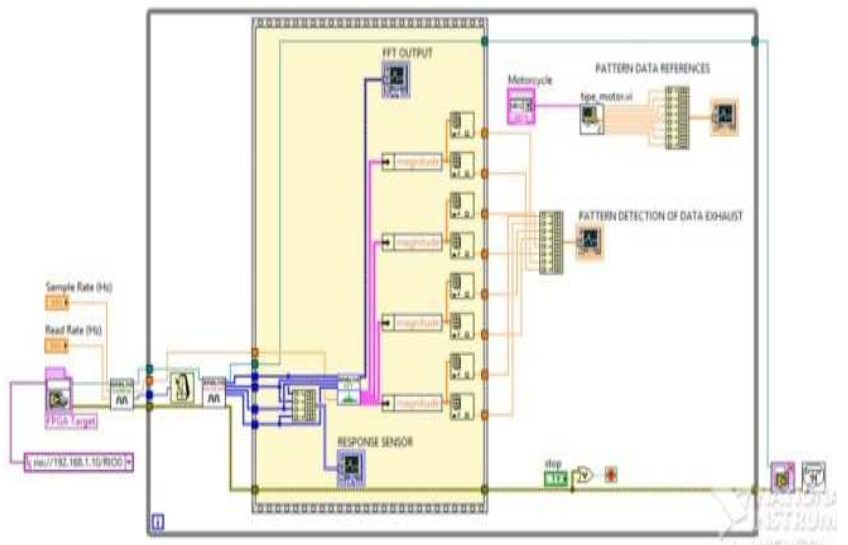

Fig.3. Data flow diagram of the system

A. The observation of combustion test data patterns as patterns of reference data.

The process begins with a tune up the engine combustion process by a motorcycle mechanic when idle. After the tune up, then the measurement of exhaust emissions by using exhaust emission analyzer to determine the levels of emissions produced. Having obtained the data pattern of the combustion engine perfectly within their category with high levels of exhaust emissions, the data retrieval is done 30 times. Changes in the value of the magnitude of the measurement results of exhaust emissions to 30 times observations on the motorcycle Honda Supra Fit shown in Figure 3. As in Figure 4 show the results of changes in the magnitude of each element and compound waste gas was observed.

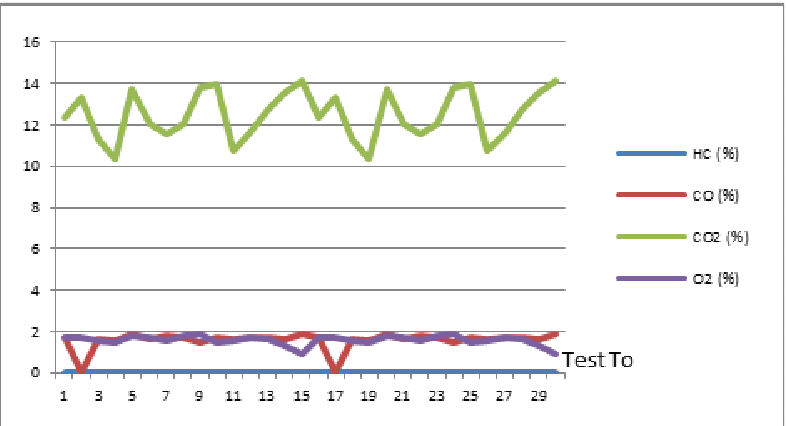

Figure 4. Results of testing with Exhaust Emission Analyzer for the 30 times observation.

To get the reference of data pattern, the data process is done by calculating the average value of magnitude of each element and compound of the exhaust gas.

Figure 5 displays the average magnitude of each data pattern obtained after 30 times of observation. Furthermore, the data pattern is used as reference data for the motorcycle Honda Supra Fit.

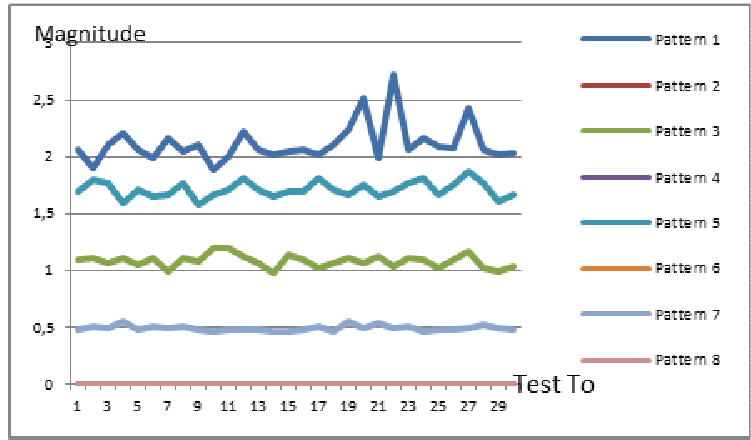

Fig.5. Changes in the value of each pattern data obtained for the 30 times of testing.

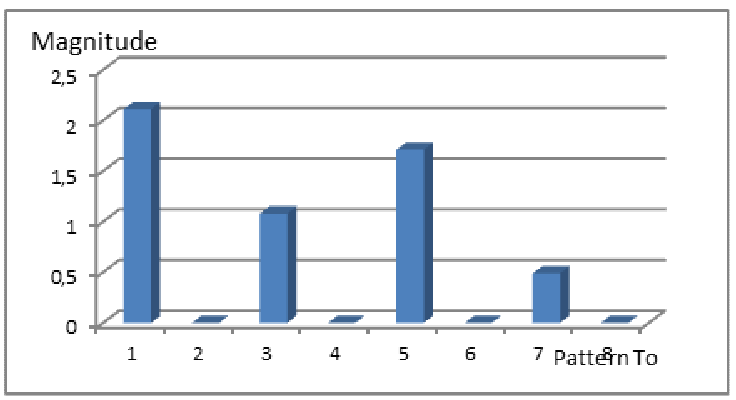

Fig. 6. Pattern data of complete combustion of motorcycle Honda Supra Fit.

In the same way as in the previous test, obtained pattern combustion reference data categories for the different motorcycles as in Figure 6. 


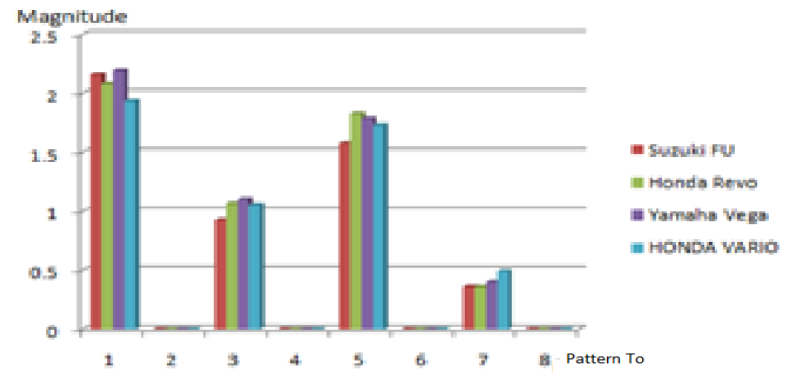

Fig. 7. Graph pattern reference data of 4 types motorcycle.

B. Observations detection test data pattern on line for motorcycles that have not, and when tune up combustion.

This test aims to determine the the system's ability to detect the combustion conditions of a motorcycle before the tune up, whe the tune up is being done and after the tune up by a mechanic. This testing process is conducted to a motorcycle with the engine with the combustion conditions that is not yet known. If the condition that is detected form the data pattern has similarities with perfect the combustion conditions, then the tune up process is done. But if the data pattern detection result are the incomplete combustion, then the tune up is performed by a mechanic simultaneously with detection by on-line tool to obtain complete combustion the data patterns.

Figure 7 displays the response time hasi test systems to respond to any changes in the elements and compounds exhaust gas on line when done tun up by a mechanic

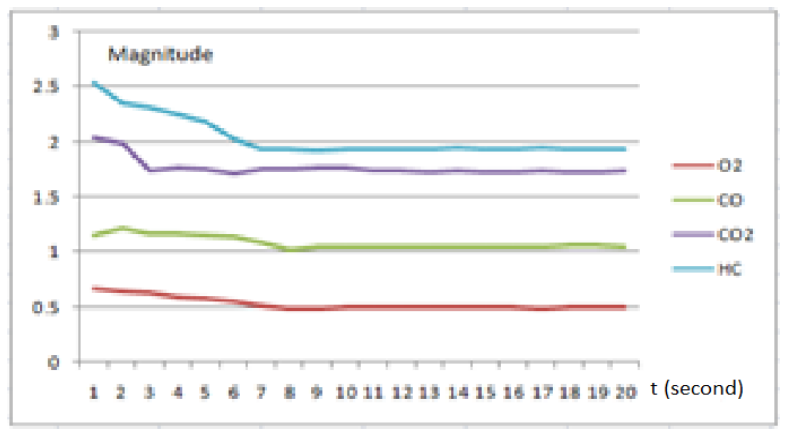

Fig.8. The response time of the system to changes in the levels of exhaust emissions.

From figure 7 obtained that, the system is able to respond changes in the levels of maximum exhaust emissions at 10 seconds. So it can be analyzed that the system will respond optimally every change in the levels of elements and compounds present in the exhaust emissions of at least 10 seconds after the tune up is done.

The data patterns before and after the tune up and compared with reference data pattern shown in Figure 8 for Honda Revo motorcycle. In the figure 8 shown that data patterns difference with magnitude value large enough data to pattern 1 and pattern 3 compared with the reference data pattern.

The difference is calculated based on the difference magnitude value that is from 0.25 to 1 and from 0,004 to the $3^{\text {rd }}$ pattern. After tune up is done, the differences in the pattern of the $1^{\text {st }}$ and $3^{\text {rd }}$ respectively become 0.1 .

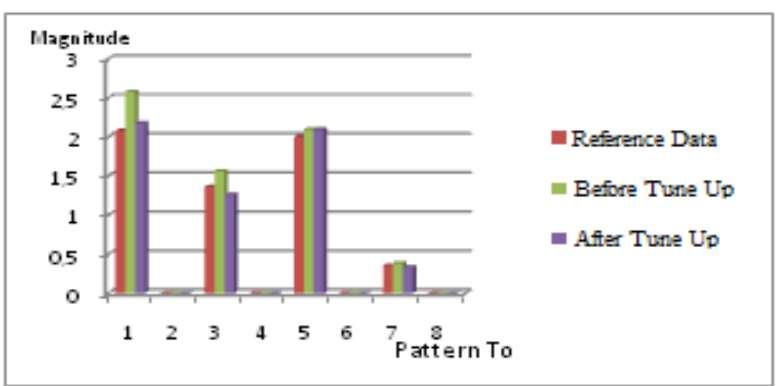

Fig. 9. The pattern of reference data, and the data pattern prior to tune up, and after tune up of Honda Revo 2010

For the data patterns that is being detected after the tune up there are similarities between the pattern of reference data with the results of the data pattern detection. So it can be declared that the result of the tune-up has managed to get the same data pattern form the reference data pattern, it is the data pattern of complete combustion.

TABLE III

SHOWS THE DIFFERENCE MAGNITUTE EACH DATA PATTERN BETWEEN REFERENCE DATA PATTERN WITH THE DATA PATTERN DETECTION RESULTS BEFORE AND AFTER TUNE UP OF HONDA REVO MOTORCYCLE.

\begin{tabular}{|c|c|c|c|r|r|}
\hline $\begin{array}{c}\text { Pattern } \\
\text { To }\end{array}$ & $\begin{array}{c}\text { Reference } \\
\text { Data }\end{array}$ & $\begin{array}{c}\text { Before } \\
\text { Tune up }\end{array}$ & $\begin{array}{c}\text { After } \\
\text { Tune up }\end{array}$ & $\begin{array}{c}\text { Before } \\
\text { (xi-yi) }\end{array}$ & $\begin{array}{c}\text { After } \\
\text { (xi-yi) }\end{array}$ \\
\hline 0 & 2.08276 & 2.58276 & 2.18276 & 0.58 & 0.1 \\
\hline 1 & 0.000119 & 0.000119 & 0.000119 & 0 & 0 \\
\hline 2 & 1.36477 & 1.56477 & 1.26477 & 0.2 & 0.1 \\
\hline 3 & 0.00013 & 0.00013 & 0.00013 & 0 & 0 \\
\hline 2 & 2.00311 & 2.10311 & 2.10311 & 0.1 & 0.1 \\
\hline 5 & 0.000128 & 0.000128 & 0.000128 & 0 & 0 \\
\hline 6 & 0.357219 & 0.387219 & 0.337219 & 0.03 & 0.02 \\
\hline 7 & $3.11 E-05$ & $3.11 E-05$ & $3.11 E-05$ & 0 & 0 \\
\hline \multicolumn{7}{|c|}{ Totalue Difference Magnitude Data } & $\mathbf{0 . 8 3}$ & $\mathbf{0 . 0 8}$ \\
\hline
\end{tabular}

From Table 3 shows the total differences that is much smaller for the comparison between the magnitude value with a reference data pattern magnitude of the data pattern detection results after the tune up is done. This indicates that it has obtained the similarity between the pattern of reference data with the data pattern is detected that the data pattern of complete combustion.

Furthermore, the test results show a motorcycle before and after tune up the engine combustion performed. The observation is shown in Figure 9.

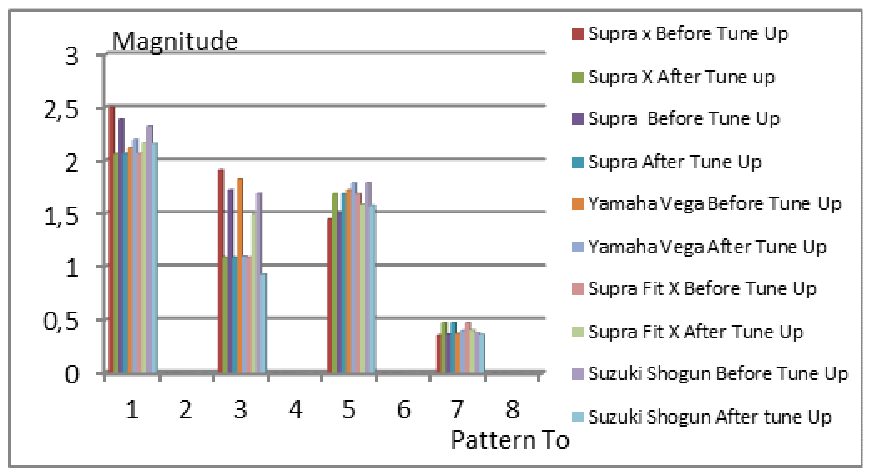

Fig. 10. Pattern data before and after a tune up several types of motorcycles. 
Data detection results before tune up in figure 9, obtained a pattern that is not the same as data pattern of a perfect combustion. After a tune up is done by a mechanic can be obtained the category of data patterns combustion that is has similarities with the reference data pattern which a perfect combustion. Thus the results of data pattern displayed this device can be used as reference data by a mechanic when tune up the combustion. The next test is done to test the form and magnitude value of the data patterns for motorcycle that have not been tune up with the different year of manufacture. The observation is displayed in the form of data pattern in Figure10.

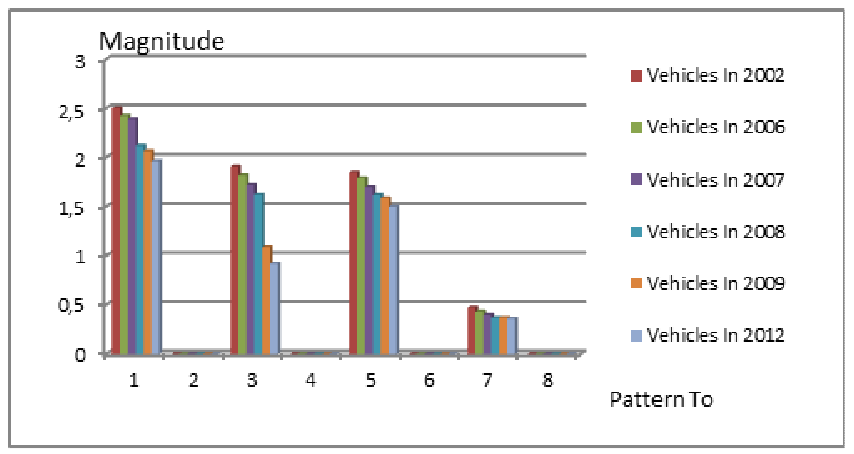

Fig. 11. Pattern Data of motorcycles based on the year of manufacture on the conditions before a tune up.

Magnitude value pattern data obtained prior to the tune-up on the figure 10 , shows the magnitude value that changes according to the age of the vehicle are detected. The older the age of the vehicle, then the value of the data pattern of higher magnitude. Thus the exhaust gas emission levels be higher if the age of the vehicle is getting old.

\section{CONCLUSIONS}

Based on the results of research and data analysis conducted in this study can be summarized as follows: There are differences in the magnitude of data patterns that characterize the condition of motorcycles combustion engine being detected. From five types of motorcycles which tested on complete combustion category, the highest magnitude value data pattern contained in the data pattern to 1 is 2.19 and the lowest in the pattern to 5 is 0.000064 .
The pattern of reference data and data pattern detection is said to have similar results if the amount of the difference in value of less than 0.1 magnitude pattern. Response time system of respond to changes in the levels of elements and compounds exhaust gas is detected when a tune up performed in real time is 10 seconds. The older the vehicle the higher the magnitude value data pattern when the combustion engine is not perfect.

\section{REFERENCES}

[1] Isnanda ,The influence of the exhaust gas to gasoline motor performance, published by the Journal of Mechanical Engineering Polytechnic Padang Volume 4 Number 1 of 2007.

[2] Mustafa Bakri, Akhmad Syarief, Ach. Kusairi. Flue gas analysis engine EFI technology with premium fuel, Technical Info, Volume 13 No. 1 July 2012.

[3] Rupali V. Chothe, Sunita P. Ugale," E-Nose for gas detection at vehicle exhaust Using supervised learning algorithm" Volume 1, Issue 4, IJETTS page 145-149, 2012.

[4] Van, Basshuysen Richard, and Fred Schäfer. Internal Combustion Engine Handbook: Basics, Components, Systems, and Perspectives.Warrendale, PA: SAE International, 2004.

[5] Gerhard Knothe,Christopher A. Sharp ,and Thomas W. Ryan http://id.wikipedia.org/wiki/ exhaust emissions . Access on March 29th 2014

[6] Mohd. Gempur Adnan,"Ambang batas emisi gas buang kendaraan bermotor lama" Peraturan Menteri Negara Lingkungan no 5 tahun 2006.

[7] Figaro Group,"Product Information Figaro OxygenSensor SK-25F", <url:http://www.figaro.com/>, 2014

[8] Hanwei electronics,mg-811 data sheet,http://www.hwsensor.com. Accessed on March 5th 2014.

[9] Ahmed Soliman, Prabhu J.Jackson,Giorgio Rizzoni and Prabir Dutta,"A sensor array for control of_engine exhaust after-treatment system",skoge/prost/proceedings/ifac 2005

[10] Keith Moore, National instruments application notes," Testing Automotive Exhaust Emissions,". 2013.

[11] Beny Setia Nugra, Application technology electronic fuel injection (EFI) to reduce exhaust emissions of motorcycles, published by the Journal of Scientific and Applied Technology program D3 Mechanical Engineering, Faculty of Engineering, State University of Semarang volume 5 number 2 in 2007.

[12] Joko Winarno,"Study of exhaust emissions of petrol-engined vehicles in various brands of vehicles and the year of manufacture', published by the Journal of Engineering, Faculty of Engineering, University of Jogyakarta Janabadra Volume 4 Number 1 in 2014

[13] Federal Communications Commission, "Engine Test Cells/Stands NESHAP." Accessed on March 25th 2015

[14] National instruments," User Guide And Specifications NI myRIO1900", National instruments 2014. 